\title{
Common calcaneal tendon repair with glycerin-preserved carotid artery xenografts and autologous bone marrow mononuclear cells in rabbits
}

\author{
Reparo de tendão calcanear comum de coelhos com xenoimplante de artéria carótida \\ preservada em glicerina associado a células mononucleares da medula óssea autólogas
}

\author{
Robson José Gomes de MELO ${ }^{1}$; Gentil Ferreira GONÇALVES ${ }^{2}$; Duvaldo EURIDES ${ }^{3}$; Patricia \\ ROMAGNOLLI ${ }^{2}$; Marshal Costa LEME ${ }^{4}$; Eduardo José de Almeida ARAÚJO ${ }^{5}$; Campo Amor Vieira \\ da CUNHA NETO ${ }^{6}$
}

\author{
${ }^{1}$ Secretaria Municipal dos Direitos dos Animais, Recife - PE, Brazil \\ ${ }^{2}$ Universidade Federal da Fronteira Sul, Curso de Medicina Veterinária, Realeza - PR, Brazil \\ ${ }^{3}$ Universidade Federal de Uberlândia, Faculdade de Medicina Veterinária, Uberlância - MG, Brazil \\ ${ }^{4}$ Universidade Federal do Espírito Santo, Curso de Medicina Veterinária, Alegre - ES, Brazil \\ ${ }^{5}$ Universidade Estadual de Londrina, Londrina - PR, Brazil \\ ${ }^{6}$ Universidade Estadual Paulista "Júlio de Mesquita Filho", Faculdade de Medicina Veterinária e Zootecnia, Departamento de Clínica \\ Veterinária, Botucatu - SP, Brazil
}

\begin{abstract}
Fifteen adult rabbits were used to evaluate the repair of experimental common calcaneal tendon defects treated with glycerin-preserved canine carotid artery xenografts alone or associated with autologous mononuclear bone marrow cells (AMCs). Rabbits were submitted to daily clinical examination; implanted sites were analyzed under light microscopy within 15, 30 and 60 days of surgery. Pelvic limbs receiving xenografts associated with AMCs had better physical performance as well as higher collagen fiber, fibroblast, lymphocyte and new vessel counts at all postoperative time points considered. Glycerin-preserved canine carotid artery xenografts associated with AMCs constituted an effective method for common calcaneal tendon repair in rabbits.
\end{abstract}

Keywords: Tendon. Surgery. Adult stem cells.

\begin{abstract}
Resumo
Utilizou-se 15 coelhos adultos para avaliar o reparo de lesão do tendão calcanear comum com implante de artéria carótida de cães, preservada em glicerina, associado ou não a células mononucleares autólogas da medula óssea (CMAs). Os animais foram observados diariamente por meio de avaliações clínicas e o local do implante foi analisado sob microscopia de luz decorridos 15, 30 e 60 dias de pós-operatório. Notou-se em todos os períodos de observação, com o implante associado às CMAs, melhor desempenho físico dos membros pélvico e maior intensidade de fibras colágenas, fibroblastos e linfócitos e neovascularização. A utilização de xenoimplante de artéria carótida de cães preservada em glicerina associado à administração de células mononucleares da medula óssea foi eficiente no reparo do tendão calcanear comum de coelhos.
\end{abstract}

Palavras-chave: Tendão. Cirurgia. Células tronco adultas.

Correspondence to:

Gentil Ferreira Gonçalves

Universidade Federal da Fronteira Sul, Campus Realeza

Rua Edmundo Gaievski, 1000

CEP 85.770-000, Cx. Postal 253, Realeza, PR, Brazil

e-mail: gentil.goncalves@uffs.edu.br

Received: $12 / 07 / 2015$

Approved: 11/09/2016

\section{Introduction}

Attempts at minimizing tendon injuries have led to several research efforts aimed at investigating materials capable of promoting healing and providing sufficient resistance to preserve tendon mechanical properties and 
maintain tendon function in lesions with substance loss and disunion of ruptured tendon ends. Common calcaneal tendon rupture is common in dogs and is often associated with disunion (KILLINGSWORTH, 1993).

The primary role of tendons is to transfer mechanical energy generated by muscular contraction to the skeleton to produce movement and, as such, involves minimal energy expenditure. Tendons are physically characterized by high resistance to tension, high density and smooth surface, but may vary in thickness, length and shape (BUTLER, 1985). Poor vascularization and predominance of tenocytes in mature tendons call for careful tendon reposition. Neovascularization and fibroblast proliferation are essential for tendon healing and must be derived from adjacent tissues; therefore, tendon repair must promote adequate contact with peripheral tissues while inducing minimal adhesion formation, which could potentially compromise tendon gliding function (RAISER, 2001).

Autologous bone marrow mononuclear cells (AMCs) are undifferentiated cells with indefinite replication or self-renewal potential. These cells can differentiate into specialized cells of different tissues and organs upon exposure to given stimuli, and may therefore be transplanted for reconstitution of tissues damaged by disease, trauma or aggressive therapies. Autologous bone marrow mononuclear cells have been employed for regeneration and functional recovery of peripheral nervous tissue in mice (BRAGASILVA et al., 2006), for treatment of corneal ulceration in dogs (TOGNOLI et al., 2008) and chronic chagasic cardiomyopathy in humans (SANTOS et al., 2004), in association with osteochondral allografts in trochlear groove repair in rabbits (SOUZA, 2009), for regeneration of insulin-producing cells (VOLTARELLI et al., 2009), in treatment of ischemic cardiomyopathy in humans (ROSSI; BOROJEVIC, 2009) and in epilepsy treatment (CARRION et al., 2009).

Young et al. (1998) investigated the use of AMCs, biodegradable collagen grafts and polyglactin 910 mesh for repair of common calcaneal tendon defects in rabbits and observed fibroblast cell growth and severe inflammatory reaction within 12 weeks of treatment. Good results regarding histological features (number of fibroblasts and mature collagen fibers) and biomechanical properties have been reported in another study involving the use of AMCs in patellar tendon repair in rabbits (AWAD et al., 1999).

Glycerin solution at $98 \%$ has been used for preservation of a variety of tissues, such as dura mater (PIGOSSI et al., 1971; INATOMI et al., 1980), peritoneum (DALECK et al., 1992; COSTA NETO et al., 1999), pericardium (RAHAL et al., 1996), phrenic center (PIGATTO et al., 1997; SARTORI FILHO et al., 1997), auricular cartilage (CONTESINI et al., 2001), amniotic membrane (OLIVEIRA; ALVARENGA, 1998), renal capsule (EURIDES et al., 2006), arteries (RAISER et al., 1978), bladder (OLIVEIRA et al., 2000), tendon (RAISER, 2000, 2001) and bone (SOUZA, 2009). Glycerin is known to have dehydrating, antiseptic and anti-immunogenic properties and not to interfere with preserved tissue characteristics (ALVARENGA, 1992).

This study aimed to investigate the functional and structural efficacy of glycerin-preserved canine carotid artery xenografts with and without AMCs in common calcaneal tendon repair in rabbits. 


\section{Material and Methods}

This project has been approved by the Animal Experimentation Ethics Committee (CEPEEA; protocol No. 15517/2009). Approval was granted for harvest of carotid arteries from euthanized dogs; harvested arteries were washed several times in running water, rinsed with $0.9 \%$ saline solution and $1 \%$ povidone-iodine and then immersed in $98 \%$ glycerin for a minimum of 30 days. Glycerinpreserved arteries were rehydrated in $0.9 \%$ saline solution containing $1 \%$ povidone-iodine for 20 min prior to use as grafts.

Fifteen male New Zealand rabbits aged between 10 and 16 months and weighing $2.8 \mathrm{~kg}$ on average were submitted to clinical examination consisting of rectal temperature measurement, cardiac and pulmonary function assessment, abdominal palpation and capillary refill time determination. Following confirmation of eligibility to participate in the experiment, rabbits were submitted to bilateral middle third common calcaneal tenotomy. Tendon defects were then treated with glycerin-preserved canine carotid artery xenografts associated with AMCs (right pelvic limbs; RPL) or glycerin-preserved canine carotid artery xenografts alone (left pelvic limbs; LPL).

Bone marrow was harvested under dissociative anesthesia with intramuscular xylazine hydrochloride, ketamine hydrochloride and fentanyl hydrochloride $(2.0 \mathrm{mg} / \mathrm{kg}, 20 \mathrm{mg} / \mathrm{kg}$ and $0.005 \mathrm{mg} / \mathrm{kg}$, respectively). The area overlying the greater trochanter of the femur was clipped and aseptically prepared; a 40x16 hypodermic needle was then inserted through the intertrochanteric fossa and $2.0 \mathrm{ml}$ of bone marrow aspirated into a $20.0 \mathrm{ml}$ syringe containing $0.1 \mathrm{ml}$ of heparin. Autologous bone marrow mononuclear cells were diluted in phosphate-buffered saline with $2 \%$ bovine fetal serum (PBS $+2 \%$ FBS) and layered onto Ficoll-Hypaque. The solution was centrifuged at room temperature $\left(15-25^{\circ} \mathrm{C}\right)$ for $30 \mathrm{~min}$ at $400 \mathrm{G}$ and the upper plasma layer removed and discarded without disturbing the plasma-Ficoll interface. The mononuclear cell layer was then removed and retained at the plasma-Ficoll interface without disturbing the erythrocytegranulocyte pellet. Mononuclear cells were washed twice in $1.0 \mathrm{ml}$ of Dulbecco's phosphate-buffered solution (DBPS) via centrifugation at $400 \mathrm{G}$ for 15 min and resuspended to $6 \times 10^{9}$ cells per $\mathrm{ml}$ of DBPS in a total volume of $0.5 \mathrm{ml}$.

Cell viability determination was based on trypan blue dye exclusion staining and calculated (\%) using the formula $\mathrm{V} \times 100 / \mathrm{TN}$ (TN, total number of viable and non-viable cells counted in Newbauer chamber). A $10 \mu$ l aliquot of the cell suspension was then removed and mixed with $10 \mu \mathrm{l}$ of trypan blue in Eppendorf tube for Newbauer chamber cell counting. Viable and non-viable cell counting was carried out under light microscopy; cell counts per $\mathrm{ml}$ were determined using the formula V x FN x FT/\#Q (v, viable cell count; NF, Newbauer chamber factor; TF, trypan blue dilution factor, and $\# \mathrm{Q}$, number of quadrants considered for cell counting in Newbauer chamber).

Following bone marrow harvest, rabbits were placed in lateral recumbency and the operating field prepared. The skin on lateral aspect of the right tibia was incised for exposure of the common calcaneal tendon. Two simple interrupted 4-0 monofilament nylon sutures were placed $0.5 \mathrm{~cm}$ distal and $0.5 \mathrm{~cm}$ proximal to the musculotendinous and the osteotendinous junction, respectively. A tendon segment approximately $1.0 \mathrm{~cm}$ long was then resected and a glycerin-preserved canine carotid artery xenograft 
sutured to the proximal and distal tendon stumps with simple interrupted 4-0 monofilament nylon sutures, so as to form a tube. Autologous bone marrow mononuclear cells were inoculated into the graft. The paratendon was closed in a simple continuous pattern and the skin in simple interrupted fashion using 5-0 and 4-0 monofilament nylon sutures, respectively. The left calcaneal tendon was submitted to the same procedure, except for AMC inoculation.

Operated limbs were protected with compressive non-adherent bandages extending from the femorotibial patellar joint down to the distal limb. Postoperative medication consisted of intramuscular cefazolin sodium $(30.0 \mathrm{mg} / \mathrm{kg}$ every $12 \mathrm{~h})$ and flunixin meglumine $(1.0 \mathrm{mg} / \mathrm{kg}$ every 24 h) for seven and three days, respectively; analgesia was achieved with subcutaneous tramadol hydrochloride $(2.0 \mathrm{mg} / \mathrm{kg})$ given every $8 \mathrm{~h}$ for three days. Surgical wounds were cleaned with gauze sponges soaked in $0.9 \%$ saline solution and treated with topical $10 \%$ povidone-iodine and rifampicin spray twice daily for seven days. Sutures were removed within 7 days of surgery.

Rabbits were randomly allocated to one of three groups $(\mathrm{n}=5)$ and assessed for lameness, frequency of limb use and standing posture on postoperative days 15,30 , and 60 . Pain sensation was determined by digital palpation and pelvic limb flexion/extension movements. At the end of the follow-up period, rabbits were euthanized with intravenous sodium thiopental $(50 \mathrm{mg} / \mathrm{kg})$ and tendon biopsy fragments collected from grafted sites for gross and histological analysis.

Specimens were fixed in $10 \%$ buffered formaldehyde solution, dehydrated in increasing concentrations of ethanol, diafanized in xylol, embedded into paraffin blocks and sectioned in microtome for slide preparation. Slides were stained with hematoxylin-eosin (HE) or Heidenhain's azan trichrome stain and submitted to light microscopy for lymphocyte, fibroblast, macrophage, mononuclear cell and new blood vessel counting. The center of each histological section was marked for cell quantification; ten central, five upper peripheral and five lower peripheral fields were then counted under $40 \mathrm{X}$ magnification. Two cell counts were performed per section (HE and azan trichrome stained slides, cells and collagen fibers respectively).

The Kruskal-Wallis and the Wilcoxon statistical tests were used for intergroup and intragroup comparisons, respectively. The level of significance was set at $5 \%(\mathrm{p}<0.05)$.

\section{Results and Discussion}

Ficoll-Hypaque density gradient centrifugation enabled good cell isolation; mean cell viability and AMC density values corresponded to $93.79 \%$ and $6.8 \times 10^{6}$, respectively. Lower values have been documented following tendon repair with osteochondral allografts inoculated with AMCs in rabbits (SOUZA, 2009). However, higher values (97.77\%) have also been reported following treatment of iatrogenic tendon lesions in this species (SOUZA, 2009).

Inoculation of glycerin-preserved canine carotid artery xenografts with AMCs stimulated fibroblast cell growth and collagen synthesis and promoted integration of grafts to tendon stumps in this study. Similar findings have been documented in rabbits treated with osteochondral allografts and bone morphogenetic protein or AMCs (SOUZA, 2009). Carotid artery grafts were stored in $98 \%$ glycerin for 30 to 180 days prior to use in this trial. This time span is thought to be sufficient to prevent graft rejection (COSTA NETO et al., 1999) 
and eliminate graft immunogenicity (DALECK et al., 1992).

Pigossi et al. (1971) observed that glycerin did not prevent growth of sporulating organisms in glycerin-preserved dura mater. Feline leukemia virus has also been found in glycerin-preserved bone (CORONADO JUNIOR et al., 1998). In this trial, graft immersion in 1:50 $1 \%$ povidoneiodine $/ 0.9 \%$ saline solution for 20 min was aimed at rehydration as well as control of infectious agents. Inflammatory responses associated with polymorphonuclear activation (i.e., infection) were not observed using this method. Also, deposition primarily of connective tissue suggests aseptic postoperative progression and regenerative tissue responses.

Rabbits in this trial resumed locomotion within two days of surgery and were not lame at the end of the first postoperative week. In contrast with limb immobilization and controlled exercise for 21 days in a canine study by Raiser (2000), only compressive non-adherent bandages were applied to the surgical site. Differences in postoperative care may have accounted for early and apparently normal (i.e., lameness-free) postoperative ambulation observed.

Within seven days of surgery, two rabbits presented with pain and lameness (RPL and LPL, respectively), which subsided over the next seven days. Surgical wounds were assessed for edema formation, healing progression and wound dehiscence. Left pelvic limb edema, partial LPL wound dehiscence (two sutures) and wound contamination were noted in one, two and one rabbit, respectively; remaining rabbits exhibited normal healing process. Surgical wounds had apparently healed and no local changes were noted within 15 days of surgery. Gross inspection findings within 15 days of surgery corresponded to tendon adhesions (RPL, one rabbit; LPL, three rabbits), neovascularization (RPL, one rabbit; LPL, three rabbits) and fibrosis (RPL, three rabbits; LPL, two rabbits). Suture material could be seen at the graft-tendon interface in all cases.

Inspection within 30 days of surgery revealed tendon adhesions (RPL, two rabbits; LPL, three rabbits) and neovascularization (RPL, three rabbits; LPL, two rabbits); fibrosis was noted in all operated limbs and suture material could be seen at the graft-tendon interface in all but one case. Within 60 days of surgery, all rabbits had developed tendon adhesions and neovascularization in both limbs; fibrosis and suture material were noted in all LPLs and in the RPL of two rabbits. Scar tissue formation was noted in all tendon stumps.

Tendons receiving carotid artery grafts inoculated with AMCs were sufficiently resistant to support lameness-free ambulation within 60 days of surgery. Similar findings have been reported by Zhao et al. (2009) following biomechanical testing, suggesting AMCs have the potential to promote tendon healing.

In a canine study evaluating calcaneal tendon repair with semitendinosus muscle flap, Baltzer and Rist (2009) stressed the significance of blood supply in the tendon repair process. In spite of better organized neovascularization in right compared to left pelvic limbs in this trial, abundant neovascularization in all limbs within 30 days of surgery indicates that tendon blood supply was not compromised.

Histological analysis revealed inflammation with predominance of mononuclear cells and new vessel formation around or inside grafts, as well as in tendons, within 15 days of surgery.

Persistence of graft invasion by blood vessels within 30 days of surgery, along with round- 
shaped fibroblasts, suggests graft incorporation into exuberant newly formed fibrous tissue. Similar findings have been reported by Costa-Neto et al. (1999).

Structures comprised of fibroblasts and fine collagen fibers suggestive of new tendon tissue were noted in limbs treated with glycerinpreserved canine carotid artery xenografts and AMCs, but not in limbs treated with glycerin- preserved canine carotid artery xenografts alone (right and left pelvic limbs respectively). Within 60 days of surgery, bundles of well-aligned fibers and spindle-shaped fibroblasts typical of mature tendon tissue (PAYNE; TOMLINSON, 1993) were visible in RPL specimens, along with cell activity and disorganized fibers (Figure 1).

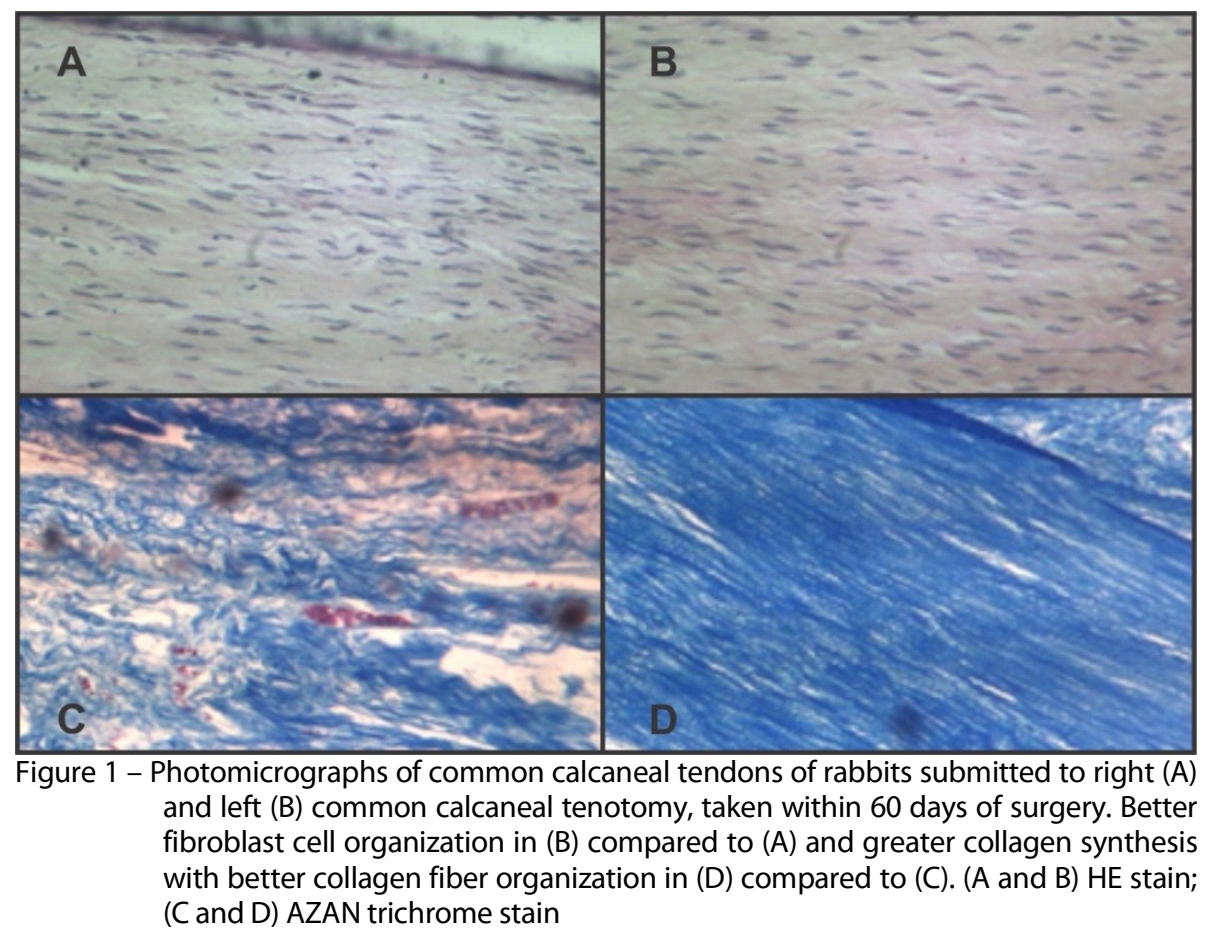

Glycerin-preserved carotid artery xenografts associated with AMCs can be easily stored and implanted, and therefore meet qualitative criteria given by Vámhidy et al. (1990). Also, the method employed for bone marrow collection (i.e., needle puncture through the intertrochanteric fossa) prevents incision-related trauma to the donor area.

Fibroblast counts were significantly $(\mathrm{p}<0.05)$ higher in right compared to left pelvic limb grafts in all rabbits, at all postoperative time points considered (Table 1). Graft inoculation with AMCs increased fibroblast counts and collagen synthesis rate in treated tendons, supporting findings of Young et al. (1998) and Awad et al. (1999).

Macrophage counts did not differ significantly between limbs in any of the three groups (Table 1), suggesting graft incorporation into new tissue rather than phagocytosis.

Polymorphonuclear cell counts and respective statistical analysis revealed significantly higher polymorphonuclear cell proliferation in right compared to left limb tendons within 15 days of surgery. Inadequate intraoperative procedures may have accounted for these differences. However, the fact that inflammation tends to peak around the 
same time and that part of the inoculated (undifferentiated) cells differentiated into polymorphonuclear cells may explain intergroup differences. Mild inflammation documented in this trial reflects the use of biological grafts, in contrast with severe inflammation elicited by synthetic grafts (YOUNG et al., 1998).

Table 1 - Mean fibroblast, macrophage, polymorphonuclear cell and new vessel counts in histological sections of rabbit common calcaneal tendons treated with glycerin-preserved canine carotid artery xenografts alone (left pelvic limb, LPL) or associated with autologous bone marrow mononuclear cells (right pelvic limb, LPL), within 15, 30 and 60 days of surgery - Umuarama - PR, 2009

\begin{tabular}{|c|c|c|c|c|c|c|c|}
\hline \multirow{2}{*}{ Variable } & & \multicolumn{2}{|c|}{15 days $\mathrm{PO}$} & \multicolumn{2}{|c|}{30 days $\mathrm{PO}$} & \multicolumn{2}{|c|}{60 days $\mathrm{PO}$} \\
\hline & & Mean & SD & Mean & SD & Mean & SD \\
\hline \multirow[t]{3}{*}{ Fibroblast } & RPL & $3123.80 \mathrm{a}$ & 197.94 & $3345.00 a$ & 175.85 & $3401.80 \mathrm{a}$ & 176.00 \\
\hline & LPL & $2127.40 \mathrm{~b}$ & 91.41 & $2245.00 \mathrm{~b}$ & 84.10 & $2231.60 \mathrm{~b}$ & 65.92 \\
\hline & Difference & $996.40 \mathrm{~A}$ & 166.13 & $1100.00 \mathrm{~A}$ & 187.33 & $1170.20 \mathrm{~A}$ & 228.41 \\
\hline \multirow[t]{3}{*}{ Macrophage } & RPL & $44.80 \mathrm{a}$ & 4.49 & $41.00 \mathrm{a}$ & 8.46 & $43.00 \mathrm{a}$ & 8.86 \\
\hline & LPL & $45.20 \mathrm{a}$ & 4.76 & $39.60 \mathrm{a}$ & 9.29 & $35.40 \mathrm{a}$ & 5.90 \\
\hline & Difference & $-0.40 \mathrm{~A}$ & 7.50 & $1.40 \mathrm{~A}$ & 10.35 & $7.60 \mathrm{~A}$ & 4.82 \\
\hline \multirow[t]{3}{*}{ Polymorphonuclear cell } & RPL & $26.80 \mathrm{a}$ & 4.60 & $27.60 \mathrm{a}$ & 5.03 & $31.20 \mathrm{a}$ & 4.87 \\
\hline & LPL & $17.20 \mathrm{~b}$ & 3.03 & $24.80 \mathrm{a}$ & 4.97 & $28.80 \mathrm{a}$ & 7.56 \\
\hline & Difference & $9.60 \mathrm{~A}$ & 4.39 & $2.80 \mathrm{~A}$ & 7.35 & $2.40 \mathrm{~A}$ & 6.82 \\
\hline \multirow[t]{3}{*}{ Neovascularization } & RPL & $41.20 \mathrm{a}$ & 10.52 & $51.80 a$ & 10.23 & $51.80 a$ & 4.60 \\
\hline & LPL & $22.60 \mathrm{~b}$ & 5.85 & $35.00 \mathrm{~b}$ & 7.14 & $42.80 \mathrm{a}$ & 9.26 \\
\hline & Difference & $18.60 \mathrm{~A}$ & 5.50 & $16.80 \mathrm{~A}$ & 3.56 & $9.00 \mathrm{~A}$ & 9.87 \\
\hline
\end{tabular}

Means with the same lower case letters in the same column (per variable) do not differ significantly; Wilcoxon test, $\mathrm{p}<0.05$ Means with the same capital letters in the same row (per variable) do not differ significantly; Kruskal-Wallis test, $\mathrm{p}<0.05$

Neovascularization differed significantly between right and left limbs tendons in this study. Significant differences noted within 15 and 30 days of surgery suggest that LPL tendon specimens were still in the inflammatory, proliferative stage of healing on postoperative day 30 . In contrast, faster neovascularization in RPL tendon specimens, which persisted between postoperative days 30 and 60 , suggests that tendons treated with AMCs were already in the remodeling phase of healing on day 60 (Table 1), possibly in response to graft inoculation with bone marrow mononuclear cells. These cells seemed to promote graft vascularization and increase the rates of new tendon tissue formation. Similar findings have been reported following the use of AMCs in association with osteochondral allografts or bone morphogenetic protein (SOUZA, 2009) in trochlear groove repair in rabbits.

\section{Conclusion}

Glycerin-preserved canine carotid artery xenografts associated with AMCs constituted an effective alternative method for common calcaneal tendon repair in rabbits. 


\section{References}

ALVARENGA, J. Possibilidades e limitações da utilização de membranas biológicas preservadas em cirurgia. In: DALECK, C. R.; BAPTISTA, L. C.; MUKAI, L. S. Tópicos em cirurgia de cães e gatos. Jaboticabal: Funep, 1992. p. 33-42.

AWAD, H. A.; BUTLER, D. L.; BOIVIN, G. P.; SMITH, F. N.; MALAVIYA, P.; HUIBREGTSE, B.; CAPLAN, A. I. Autologous mesenchymal stem cell-mediated repair of tendon. Journal of Tissue Engineering, v. 5, n. 3, p. 267277, 1999. doi: 10.1089/ten.1999.5.267.

BALTZER, W. I.; RIST, P. Achilles tendon repair in dogs using the semitendinosus muscle: surgical technique and short-term outcome in five dogs. Veterinary Surgery, v. 38, n. 6, p. 770-779, 2009. doi: 10.1111/j.1532-950X.2009.00565.x.

BRAGA-SILVA, J.; GEHLEN, D.; ROMAN, J. A.; MENTA, C.; ATKINSON, E. A.; MACHADO, D. C.; VIEZZER, C.; BARBOSA, G. L.; BAES, C. V. W.; SILVA, V. D.; COSTA, J. C. Efeitos das células tronco adultas de medula óssea e do plasma rico em plaquetas na regeneração e recuperação funcional nervosa em um modelo de defeito agudo em nervo periférico em rato. Acta Ortopédica Brasileira , v. 14, n. 5, p. 273-275, 2006. doi: 10.1590/S1413-78522006000500009 .

BUTLER, H. C. Surgery of tendinous injuries and muscle injuries. In: NEWTON, C. D.; NUNAMAKER, D. M. Textbook of small animal orthopaedics. Philadelphia: J. B. Lippincolt, 1985. p. 835-842.

CARRION, M. J. M.; VENTURIN, G. T.; COSTA, J. C. Potencial terapêutico das células-tronco de medula óssea no tratamento da epilepsia. Revista Brasileira de Hematologia e Hemoterapia, v. 31, p. 112-119, 2009. Supplement 1. doi: 10.1590/S1516-84842009005000023.

CONTESINI, E. A.; SALLES, M. S.; PIGATTO, J. A. T.; PIPPI, N. L.; RAISER, A. G. Reparação traqueal em cães: transplante autógeno vs implante homógeno conservado em glicerina a $98 \%$ de cartilagem da pina. Ciência Rural, v. 31, n. 4, p. 633637, 2001. doi: 10.1590/S0103-84782001000400012.

CORONADO JUNIOR, G. S.; MARTINEZ, S. A.; SWENSON, C. L. Virucidal and osteogenic effects of $98 \%$ glycerol and ethylene oxide preservation of bone allograft in the cat. In: ANNUAL CONFERENCE OF VETERINARY ORTHOPEDIC SOCIETY, 25., 1998, Colorado, USA. Proceedings... Snowmass: Veterinary Orthopedic Society, 1998. p. 31.
COSTA NETO, J. M.; DALECK, C. R.; ALESSI, A. C.; BRACCIALLI, C. S. Tenoplastia experimental do calcâneo em cães com peritônio bovino conservado em glicerina. Ciência Rural, v. 29, n. 4, p. 697-703, 1999. doi: 10.1590/S0103-84781999000400021.

DALECK, C. R.; PADILHA FILHO, J. G.; DALECK, C. L. M.; COSTA NETO, J. M. Reparação de hérnia perineal em cães com peritônio de bovino conservado em glicerina. Ciência Rural, v. 22, n. 2, p. 179-183, 1992. doi: 10.1590/S0103-84781992000200010.

EURIDES, D.; DALECK, C. R.; SILVA, M.; SILVA, L. A. F.; GONÇALVES, G. F.; PRIETO, L. A.; BORREZZI, C. Utilização da cápsula esplênica de bovino na ceratoplastia lamelar em coelhos. Arquivos de Ciências Veterinárias e Zoologia da UNIPAR, v. 9, n. 2, p. 117-121, 2006.

INATOMI, L. S.; PRANTONI, G. A.; ARAÚJO, F. C.; RAISER, A. G.; PEREIRA, S. N.; CARDOSO, G.; BARROS, S. S.; SANTOS, M. N. Implante de dura-máter heteróloga em cães. Revista do Centro de Ciências Rurais, v. 10, n. 3 , p. 291-297, 1980.

KILLINGSWORTH, C. R. Repair of injured peripheral nerves, tendons and muscles. In: HARARI, J. Surgical complications and wound healing in the small animal practice. Philadelphia: W. B. Saunders, 1993. p. 169-202.

OLIVEIRA, L. O.; PIPPI, N. L.; GRAÇA, D. L.; FARIA, R. X.; GUIMARÃES, L. D.; GUEDES, A. G. P.; PELLEGRINI, L. C.; FERNANDES, R. R.; ALVES, A. S. Implante homógeno de bexiga conservada em glicerina $98 \%$ para reparo da bexiga de cães. Arquivos da Faculdade de Veterinária UFRGS , v. 27, n. 1, p. 90-102, 2000.

OLIVEIRA, V. A.; ALVARENGA, J. Membrana amniótica preservada em glicerina no reparo de feridas cutâneas de membros locomotores de equinos. Ciência Rural, v. 28, n. 4, p.623-628, 1998. doi: 10.1590/S0103-84781998000400014.

PAYNE, J. T.; TOMLINSOM, J. L. Composition, structure, and function of muscle, tendon and ligament. In: BOJRAB, M. J. Disease mechanisms in small animal surgery. $2^{\text {nd }}$ ed. Philadelphia: Lea \& Febiger, 1993. p. 656-662.

PIGATTO, J. A. T.; PIPPI, N. L.; MARCHIONATTI, A. E.; SOUZA, R. L.; GODOY, C. L. B.; GRAÇA, D. L. Enxerto homólogo de centro frênico, preservado em glicerina, na reconstrução parcial de parede esofágica cervical em 
caninos. Arquivos da Faculdade de Veterinária UFRGS, v. 25, n. 2, p. 116-124, 1997.

PIGOSSI, N.; RAIA, A.; LEX, A. Estudo experimental e clínico sobre o emprego, como implante, da dura-mater homógena conservada em glicerina à temperatura ambiente. Revista da Associação Médica Brasileira , v. 17, n. 8, p. 263278, 1971.

RAHAL, S. C.; BACARENSE, A. P. F. R. L.; MIGLIATI, E. R.; PADOVONI, C. F.; IAMAGUTI, P. Implantação intraorbital, após a enucleação transpalpebral, de resina acrílica ou pericárdio em coelhos. Ciência Rural, v. 26, n. 2, p. 229-233, 1996. doi: 10.1590/S0103-84781996000200010.

RAISER, A. G. Homoimplante ortotópico de tendão calcâneo comum, preservado em glicerina a 98\%, e tratado com radiação laser Arseneto de Gálio, sob dois métodos de imobilização em cães. 2000. 88 f. Tese (Doutorado em Cirurgia) - Programa de Pós-graduação em Medicina Veterinária, Universidade Federal de Santa Maria, Santa Maria, 2000.

RAISER, A. G. Reparação do tendão calcâneo em cães. Ciência Rural, v. 31, n. 2, p. 351-359, 2001. doi: 10.1590/S0103-84782001000200027.

RAISER, A. G.; PEREIRA, S. N.; CARDOSO, G. Revascularização periférica com artéria conservada em glicerina. Revista do Centro de Ciências Rurais, v. 8, n. 3, p. 251-255, 1978.

ROSSI, M. I. D.; BOROJEVIC, R. Terapias celulares do miocárdio com células da medula óssea: critérios de qualidade e perspectivas. Revista Brasileira de Hematologia e Hemoterapia, v. 31, p. 82-86, 2009. Supplement 1. doi: 10.1590/S1516-84842009005000033.

SANTOS, R. R.; SOARES, M. B. P.; CARVALHO, A. C. C. Transplante de células da medula óssea no tratamento da cardiopatia chagásica crônica. Revista da Sociedade Brasileira de Medicina Tropical, v. 37, n. 6, p. 490-495, 2004. doi: 10.1590/S0037-86822004000600012.
SARTORI FILHO, R.; GANDOLFI, W.; BANDARRA, E. P. Emprego de membrana biológica (centro frênico) na reparação das lesões tendíneas em coelhos. Veterinária e Zootecnia, v. 9, p. 69-77, 1997.

SOUZA, L. A. Enxerto osteocondral alógeno, associado à inoculação de células mononucleares autólogas da medula óssea no reparo do sulco troclear de coelhos . 2009. 67 f. Dissertação (Mestrado em Ciências Veterinárias) - Faculdade de Medicina Veterinária, Universidade Federal de Uberlândia, 2009.

TOGNOLI, G. K.; OLSSON, D. C.; MARTINS, D. B.; SANTOS JUNIOR, E. B.; SALBEGO, F. Z.; OLIVEIRA, G. K.; BRAGA, F. V. A.; RAISER, A. G.; DEZENGRINI, R.; CRUZ, F. S. F.; CASTRO, M. B.; ROSA, M. C.; CARREGARO, A. B.; PIPPI, N. L. Transplante autólogo de células mononucleares da medula óssea em úlcera de córnea experimental em cães. Ciência Rural , v. 39, n. 1, p. 148-155, 2008. doi: 10.1590/S0103-84782008005000039.

VÁMHIDY, L.; STRAUCH, B.; BIRÓ, V. Preserved tendon grafts in reconstructive hand surgery: a review. Acta Chirurgica Hungarica, v. 31, n. 3, p. 209-215, 1990.

VOLTARELLI, J. C.; COURI, C. E. B.; RODRIGUES, M. C.; MORAES, D. A.; STRACIERI, A. B. P. L.; PIERONI, F.; NAVARRO, G.; MADEIRA, M. I. A.; SIMÕES, B. P. Terapia celular no diabetes mellitus. Revista Brasileira de Hematologia e Hemoterapia, v. 31, p. 149-156, 2009. Supplement 1. doi: 10.1590/S1516-84842009005000036.

YOUNG, R. G., BUTLER, D. L.; WEBER, W.; CAPLAN, A. I.; GORDON, S. L.; FINK, D. J. Use of mesenchymal stem cells in a collagen matrix for Achilles tendon repair. Journal of Orthopaedic Research, v. 16, n. 4, p. 406-413, 1998. doi: 10.1002/jor.1100160403.

ZHAO, C.; CHIEH, H. F.; BAKRI, K.; IKEDA, J.; SUN, Y. L.; MORAN, S. L.; AN, K. N.; AMADIO, P. C. The effects of bone marrow stromal cell transplants on tendon healing in vitro. Medical Engineering \& Physics, v. 31, n. 10, p. 12711275, 2009. doi: 10.1016/j.medengphy.2009.08.004. 